KATARZYNA KABACIŃSKA-ŁUCZAK

Uniwersytet im. Adama Mickiewicza

$w$ Poznaniu

MONIKA NAWROT-BOROWSKA

Uniwersytet Kazimierza Wielkiego

w Bydgoszczy

\title{
DZIECIĘCE ZABAWKI ŚWIĄTECZNE \\ W ŚWIETLE WYBRANYCH ŹRÓDEŁ IKONOGRAFICZNYCH 2. POLOWY XIX I POCZĄTKU XX WIEKU
}

\begin{abstract}
AвSTRACT. Kabacińska-Łuczak Katarzyna, Nawrot-Borowska Monika, Dziecięce zabawki świąteczne w świetle wybranych źródet ikonograficznych 2. połowy XIX i poczatku XX wieku [Children's Christmas Toys in the Light of Selected Iconographic Sources from the 2nd Half of the 19th and the Beginning of the 20th Century]. Studia Edukacyjne nr 46, 2017, Poznań 2017, pp. 89-112. Adam Mickiewicz University Press. ISSN 1233-6688. DOI: 10.14746/se.2017.46.7

The aim of this study is the reconstruction of children's toys received by them during the Christmas period in the second half of the 19th and at the beginning of the 20th century. In its subject matter, the article refers, on the one hand, to the deliberations about Christmas toys and, on the other hand, it is part of the ever-growing trend of research on children's toys from the historical and pedagogical perspective. The text is part of the triptych prepared by the authors on the subject of children's Christmas toys during the period of Partitions of Poland. Selected iconographic sources - press graphics, Christmas postcards and photographs on which children's toys can be found, comprise the source basis of this part. They are sources important for cognitive reasons, because they show the image of toys of the time, their appearance, shape, size, the way they were made, decorated, etc. They also indicate which toys were particularly popular (fashionable) and liked by children in the analysed period, and show the ways they were used.
\end{abstract}

Key words: children's toys, Christmas, gifts, iconographic sources, second half of the 19th and beginning of the 20th century, press graphics, Christmas cards, photography

\section{Wprowadzenie}

Życie człowieka dzieli się między czas pracy i czas świętowania. Pierwszy zabezpiecza jednostkę finansowo, daje poczucie samorealizacji, drugi jest czasem odpoczynku i zabawy, ale też refleksji i zadumy. Te dwie perspekty- 
wy już od narodzin determinują ludzką egzystencję, wprowadzają pewien porządek, powtarzalność, dają poczucie bezpieczeństwa i przynależności do grupy społecznej. Czas świętowania w społeczeństwach dawnych był związany przede wszystkim w uroczystościami religijnymi.

Obrzędy i rytuały obejmują różnorakie dziedziny, poprzez które człowiek wprowadzony zostaje w wydarzenia o charakterze nadprzyrodzonym, świętym, świątecznym, ale i uświęcającym².

\section{Według Kazimierza Żygulskiego,}

święto jest fazą szczególnie intensywnej inicjacji i socjalizacji kulturalnej jednostki, która wtedy właśnie może bardzo aktywnie, od wieku dziecięcego, uczestniczyć zwykle zarówno w przygotowaniu dnia świątecznego, jak i jego przebiegu³ .

Podobnie uważał XIX-wieczny publicysta i pisarz religijny Marian Bartynowski ${ }^{4}$, który powołując się na słowa Korneliusza Tacyta, napisał:

sposób myślenia, zamiary i chęci nasze potrafimy okazać na zewnątrz a nawet uwiecznić tylko w naszych zwyczajach i obyczajach, słowem w postępowaniu naszem ${ }^{5}$.

Refleksje te w pełni korespondują z obchodami świąt Bożego Narodzenia - świąt, które

wpisały się $\mathrm{w}$ tradycję chrześcijańską jako swego rodzaju zawłaszczenie rzymskich Saturnaliów - święta Niezwyciężonego Słońca, obchodzonego w dniach 17-24 grudnia. Ze świętami Bożego Narodzenia zbiegało się także wiele kultów słowiańskich był to czas magiczny ${ }^{6}$.

${ }^{1}$ Por. K. Kabacińska-Łuczak, K. Ratajczak, Dynamika przemian od społeczeństwa tradycyjnego do ery nowoczesności, [w:] Rekonstrukcje tożsamości w kulturze natychmiastowości, red. D. HejwoszGromkowska, Poznań 2014, s. 23-98; tychże, Dziecko chłopskie w czasie sacrum - konteksty edukacyjne (średniowiecze-epoka nowożytna), Studia Edukacyjne, 2013, 28.

${ }^{2}$ H. Nadrowski, Sacrum czasoprzestrzeni - reinterpretacja - kontrowersje - świat wartości, Toruń 2012, s. 49-50; por. K. Kabacińska-Łuczak, M. Nawrot-Borowska, Co podarować dziecku na Gwiazdkę? Porady pedagogiczne i oferty reklamowe dla kupujących zabawki z II potowy XIX i początku XX wieku, [w:] Dom - codzienność i święto. Ceremonie i tradycje rodzinne. Studia historyczno-antropologiczne, red. B. Popiołek, M. Gadocha, A. Chłosta-Sikorska, Kraków 2018 (w druku).

${ }^{3}$ K. Żygulski, Święto i kultura. Święta dawne i nowe. Rozważania socjologa, Warszawa 1981, s. 48.

${ }^{4}$ Por. Bartynowski Marian (1866-1936) pisarz religijny, publicysta, dziennikarz, Bibliografia Historii Wielkopolski za lata 1939-2000 osoby A-Ż, Biblioteka PTPN, http:/ /www.biblioteka.ptpn. poznan.pl/sites/default/files/bibliografiaosoby.pdf, (22.02.2018).

${ }^{5}$ M. Bartynowski, Obchód świąt Bożego Narodzenia w Polsce. (Kilka szczegółów z dziedziny prawa kanonicznego i archeologii), Kraków 1887, s. 3.

${ }^{6} \mathrm{O}$ ludowych czarach w średniowieczu, w których uczestniczyły dzieci i młodzież, wspomina w swych kazaniach morawski benedyktyn Jan z Holešvowa (1366-1436), zob.: B. Wojciechowska, Od Godów do świętej Łucji. Obrzędy doroczne w Polsce późnego średniowiecza, Kielce 2000, s. 24, por. K. Kabacińska-Łuczak, K. Ratajczak, Dziecko chłopskie w czasie sacrum. 
Niewątpliwie, czas Bożego Narodzenia obfitował w wiele zwyczajów, w których uczestniczyły dzieci i młodzież, kształtując w ten sposób, w procesie transmisji kulturowej, kompetencje kulturowe. Ów kapitał był kształtowany także poprzez uczestnictwo w obrzędach bożonarodzeniowych. Do jednych z nich należało wręczanie podarków, „wpisane” w tradycję, której elementami były na przykład modlitwa przed otrzymaniem prezentu, rozmowa z Gwiazdorem, wysłuchanie moralizatorskich zaleceń wychowawczych itp. Do dziecięcych wymarzonych prezentów wywołujących radość i szczęście należały oczywiście zabawki, ilustrowane książeczki, łakocie - słodycze, owoce, bakalie. Na terenie ziem polskich w XIX wieku zwyczaj obdarowywania dzieci upominkami $\mathrm{w}$ okresie świątecznym miał miejsce głównie $\mathrm{w}$ rodzinach zamożnych - arystokratycznych, ziemiańskich, czy mieszczańskich ${ }^{7}$.

Okres świąteczny na obszarze ziem polskich obchodzono kilka dni, łącząc schyłek starego oraz początek nowego roku. Czas ten nazywano godami. „Gody” znaczą czas od Bożego Narodzenia do Trzech Króli, w którym wszystkie wieczory nazywano „świętemi”, wystrzegając się podczas tychże wszelkiej pracy, spędzając czas wyłącznie na wzajemnych odwiedzinach, ugaszczaniu i śpiewaniu prastarych pieśni, które duchowieństwo postarało się zastąpić jasełkami i kolędami o narodzeniu Jezusa Chrystusa. „Wyrażenie «od god» znaczy w jednych stronach od Bożego Narodzenia, a w innych od Nowego Roku"8 - czytamy w Encyklopedii staropolskiej Zygmunta Glogera.

Prezenty dzieci znajdowały jednak nie tylko pod choinką w dzień Wigilii, ale otrzymywały je także z okazji Nowego Roku. Ten staropolski zwyczaj nazywano Kolendąa ${ }^{9}$ a praktykowano go szczególnie w ziemiańskich dworach i związany był z odwiedzinami wiejskich kolędników, którzy w zamian za pieśni i życzenia otrzymywali dary - smakołyki, alkohol, czy pieniądze. Wręczanie upominków w dzień Nowego Roku miało zapewnić szczęście i pomyślność na cały kolejny rok.

Żaden dzień nie jest tak powszechnie żądany i oczekiwany jak dzień Nowego Roku, o żadnym tyle nie mówią, na żaden tyle przygotowań nie robią (...) Zgoła wszyscy się na ten dzień cieszą. Starzy mają nadzieję, że lepiej będzie w tym roku jak w przeszłym,

${ }^{7} \mathrm{~W}$ rodzinach chłopskich podtrzymywano "stare” tradycje zdobienia izby. W opracowaniach o chłopskich zwyczajach i obchodach świąt Bożego Narodzenia z II poł. XIX wieku i pocz. XX stulecia niewiele jest informacji o choince, podarkach świątecznych, por. np. W. PrzerwaTetmajer, Gody i godne święta czyli Okres świąt Bożego Narodzenia w Krakowskiem, Kraków 1898; J. Kantor, Zwyczaje świąt Bożego Narodzenia i Wielkiej Nocy w okolicy Jarosławia, Kraków 1913.

${ }^{8}$ Gody, [w:] Z. Gloger, Encyklopedia staropolska, t. II, Warszawa 1901, s. 196; por. W. PrzerwaTetmajer, Gody i godne święta, s. 1 .

9 Historia kolędy, sięgająca jeszcze czasów pogańskich, oraz obchodzenia Godów, świąt spotkania się starego i nowego roku oraz wręczania z tej okazji podarków, zob.: Kolęda, [w:] Z. Gloger, Encyklopedia staropolska, t. III, Warszawa 1902, s. 56-59; zob. też: Wilja, tamże, t. I, 1900, s. 437; Gody, tamże, t. II, 1901, s. 196. 
młodzież się raduje, że w nowym roku zaczną się zapusty, a dzieci skaczą z ukontentowania, bo myślą, że jaką kolędę dostaną ${ }^{10}$

czytamy w jednej z powiastek Klementyny z Tańskich Hoffmanowej z początku XIX wieku. Kolęda dla dzieci składała się najczęściej z zabawek czy książeczek, ponieważ „Na Nowy Rok (...) grzecznym dzieciom dają się zabawki i inne podarunki"11. Upominki rozdawano także w dzień Trzech Króli, na pamiątkę darów ofiarowanych Jezusowi przez trzech mędrców. Nazywany był on szczodrym dniem, a poprzedzający go wieczór - szczodrym wieczorem. To właśnie tego wieczoru rozdawano służbie, krewnym i dzieciom drobne prezenty oraz pierożki, zwane szczodrakami ${ }^{12}$.

Zwyczaj wkładania upominków pod choinkę przywędrował na teren ziem polskich z Niemiec, wraz z samą choinką jako symbolem świąt Bożego Narodzenia. Przywoływany już Zygmunt Gloger tak opisuje ten obyczaj:

Za t. zw. „czasów pruskich" t. j. w latach 1795-1806, przyjęto w Warszawie od Niemców zwyczaj w wigilię Bożego Narodzenia ubierania dla dzieci sosenki lub jodełki orzechami, cukierkami, jabłuszkami z mnóstwem świeczek woskowych lub kawałków stoczka różnokolorowego. Pierwej był w Polsce tylko zwyczaj zawieszania w dniu tym u belek w izbie "gwiazdek" robionych z różnokolorowych opłatków na pamiątkę gwiazdy, symbolizującej narodziny Zbawiciela (...) Podarunki, dawane w dniu tym dzieciom i domownikom, zowią się: „na gwiazdkę"13.

${ }^{10}$ Styczeń. Kolęda, [w:] Powieści moralne dla dzieci przez autorkę Pamiątki po dobrej matce, Warszawa 1820 , s. 3.

${ }^{11}$ Zabawki z lalka. Obrazek I. Wandzia znajduje lalke, [w:] Lalka. Podarunek młodym panieneczkom z obrazkami. Rozmowy, powiastki, bajeczki dla dzieci, Lwów, ok. 1850, s. 2.

12 Szczodry wieczór, [w:] Z. Gloger, Encyklopedia staropolska ilustrowana, tom IV, Warszawa 1903, s. 308-309.

13 Gwiazdka, [w:] Z. Gloger, Encyklopedia staropolska ilustrowana, Warszawa 1901, s. 226; Podobnie wyjaśniano na łamach czasopisma „Myśl Niepodległa” z 1910 r., dodatkowo szczegółowo opisując okoliczności obdarowywania dzieci na Gwiazdkę, zwaną także Choinką czy Drzewkiem: „Wilia Świąt Bożego Narodzenia zowie się w mowie potocznej Gwiazdką (...) w ów dzień zaczęto zawieszać u powały gwiazdki, uklejone z różnokolorowych opłatków na pamiątkę gwiazdy, przyświecającej w Betlejemie (...) Po spożyciu uczty wigilijnej jedna ze starszych osób prowadzi dzieci do ciemnego pokoju i tam daje im do zrozumienia, że horoskopy co do „Gwiazdki”, ,Choinki” czy „Drzewka” przedstawiają się bardzo źle, gdyż dzieci w ciągu roku były niegrzeczne. Tymczasem reszta osób starszych w innym pokoju zapala choinkę, czyni ostateczny przegląd darów, które, o ile to tylko możliwe, wiesza się na drzewku, a wreszcie, bierze się dzwonek i dzwoni. Dzieci już wiedzą, że sygnał ten wzywa je do zapalonej choinki. Następuje najbardziej radosna chwila w życiu rodzinnym. Uczucie błogiego szczęścia ogarnia wszystkich. Na choince pali się mnóstwo świeczek, cała choinka jest obwieszona złoconymi orzechami, piernikami, jabłkami, girlandami kolorowych papierków. Pod choinką, u jej pnia, stoi Szopka, czyli Stajenka Betlejemska, z wyobrażeniem Dziewicy Marii, św. Józefa, Dzieciątka Jezus w żłobie, osiołka, wołu, pastuszków (...) Gwiazdka jako uroczystość rodzinna jest tak silnie związana z naszym życiem obyczajowym, że gdyby się ją zniosło, wyrządziłoby się krzywdę ogółowi, a przede wszystkim dzieciom, które chwilę tę zaliczają do najpiękniejszych w swoim życiu i nieraz jeszcze wspominają ją rzewnie w późnej starości (...)”, „Myśl Niepodległa” 1910, nr 156, s. 1729-1731. 
Zwyczaj więc darowywania dzieciom podarunków w dniu Wigilii nazywano Gwiazdką ${ }^{14}$. W praktyce jednak terminów kolęda czy gwiazdka używano zamiennie, określając zwyczaj obdarowywania się nawzajem w wieczór wigilijny prezentami. „Podarunki nazywane kolendą rozdają się w Wigilię narodzin Chrystusa, czyli w wigilię Bożego Narodzenia"15.

\section{Cel, ustalenia terminologiczne i możliwości źródłowe}

Celem niniejszych rozważań jest rekonstrukcja zabawek dziecięcych otrzymywanych podczas świąt Bożego Narodzenia. Artykuł w swojej tematyce nawiązuje z jednej strony do rozważań nad zabawkami świątecznymi ${ }^{16}$, $\mathrm{z}$ drugiej - wpisuje się w coraz prężniej rozwijający się nurt badań nad zabawkami dziecięcymi z perspektywy historyczno-pedagogicznej ${ }^{17}$. Ponadto, dawanie dzieciom prezentów stanowi ponadczasową tradycję świąt Bożego Narodzenia. W okresie przedświątecznym współcześni rodzice mają podobne dylematy, jak ich przodkowie w 2. połowie XIX wieku i na początku ubiegłego stulecia: jakie zabawki kupić, gdzie i w jakiej cenie, ile przedmiotów zabawy podarować, z czego mają być wykonane, jak mają wyglądać itp. Pytania te stawiało się i nadal stawia najczęściej właśnie w czasie przedświątecznym.

Wśród bogactwa źródeł historycznych pozyskanych do analizy problematyki zabawek świątecznych warto wskazać: źródła materialne, teksty pisane

${ }^{14}$ Gwiazdka: (...) podarunek, ofiarowywany dzieciom w Wigilję Bożego Narodzenia, [w:] M. Arcta, Stownik ilustrowany jezzyka polskiego, Warszawa 1916, s. 402.

${ }^{15}$ L. Biart, Pogadanki braci z siostrami, spisane ku zabawie młodych czytelników, przekł. J. Chęciński, Warszawa 1875, s. 177.

${ }_{16}$ Por. M. Nawrot-Borowska, K. Kabacińska-Łuczak, Co podarować dziecku na Gwiazdkę? Kolejna publikacja obu autorek z tego cyklu będzie dotyczyć zabawek świątecznych w tekstach literackich i czasopismach adresowanych do dzieci - materiał w opracowaniu.

17 Por. wybrane artykuły: D. Żołądź-Strzelczyk, "A cacek też dużo było”. Zabawki dziecięce na ziemiach polskich w średniowieczu i epoce nowożytnej, Kwartalnik Historyczny, 2013, 1, taże, Rola zabawek w przygotowaniu do petnienia ról społecznych kobiecych i męskich w epoce nowożytnej, [w:] Kobieta i mężczyzna jedna przestrzeń - dwa światy, red. B. Popiołek, A. Chłosta-Sikorska, M. Gadocha, Warszawa 2015; K. Kabacińska, Zabawy i zabawki dziecięce w świetle polskiej nowelistyki pozytywistycznej, Zabawy i Zabawki, 2008, 1-4, taże, Od grzechotki do... - stów kilka o zabawkach dziecięcych, Studia Edukacyjne, 2010, 11; M. Nawrot-Borowska, Zabawy i zabawki dziecięce w drugiej połowie XIX i na poczatku XX wieku - wybrane problemy z wykorzystaniem grafik z epoki, Biuletyn Historii Wychowania, 2013, 30, taże, Obrazki z dziejów lalki, [w:] Z badań nad tradycja polskiej pedagogiki, t. 2: Księga jubileuszowa dedykowana Profesor Danucie Koźmian, red. E. Magiera, J. Król, Szczecin 2016; wybrane pozycje książkowe: K. Kabacińska, Zabawy i zabawki dziecięce w osiemnastowiecznej Polsce, Poznań 2007; D. Żołądź-Strzelczyk, K. Kabacińska (red.), Dawne zabawy dziecięce, Kielce - Warszawa 2008; tychże, Dawne i wspótczesne zabawki dziecięce, Poznań 2010; tychże, Zabawka - przedmiot ludyczny i obiekt kolekcjonerski, Poznań 2016; D. ŻołądźStrzelczyk i in., Dzieje zabawek dziecięcych na ziemiach polskich do początku XX wieku, Wrocław 2016 - tutaj szczegółowa bibliografia dotycząca problematyki zabawek dziecięcych s. 437-457. 
oraz materiały ikonograficzne ${ }^{18}$. Wykorzystane w niniejszej analizie wybrane źródła ikonograficzne - grafiki prasowe ${ }^{19}$, pocztówki i fotografie, na których można znaleźć zabawki dziecięce - są istotne ze względów poznawczych, ponieważ ukazują obraz ówczesnych zabawek - ich wygląd, kształt, wielkość, sposób wykonania, zdobienia itp. Wskazują też, jakie zabawki były szczególnie popularne (można nawet użyć stwierdzenia - modne) i lubiane przez dzieci w danym okresie. Na wskazanych źródłach najczęściej przedstawione są same zabawki lub dziecko z zabawkami. Niestety, w analizowanych materiałach rzadko został uchwycony moment dzieci bawiących się danymi zabawkami w świątecznej atmosferze. Źródła ikonograficzne są więc cennym materiałem do badania zabawek dziecięcych, zaś szczególnie ważny jest ich przekaz. Dla historyka wychowania analizującego zabawkę nie jest priorytetowa technika wykonania czy wartość artystyczna dzieła ikonograficznego. Istotny jest właśnie ów przekaz, dający badaczowi przede wszystkim odpowiedź na pytania: jak wyglądała zabawka - w kontekście niniejszej analizy - zabawka podarowana dziecku na święta Bożego Narodzenia, jakie miała kształty, jaka była reakcja dziecka na otrzymany prezent, w jaki sposób ją wykorzystywało w zabawie itp.

Za zabawkę - w interesującym nas okresie - został uznany każdy przedmiot wykonany celowo do zabawy. Stownik jezzyka polskiego Samuela Bogusława Linde z 1814 roku zabawkami określał: „,zabaweczki, którymi dzieci się bawią, lalki itp." ${ }^{20}$. Natomiast definicja zabawki znajdująca się w Stowniku języka polskiego z roku 1861 ma kilka znaczeń. Z punktu widzenia naszych rozważań ważne są dwa: pierwsze - „przedmiot do zabawy, rozrywki” oraz drugie „rzecz drobna, umyślnie dla zabawy dzieci robiona, np. lalki, koniki, itp." ${ }^{21}$.

18 Źródła historyczne wykorzystywane w analizie zabawek dziecięcych: poradniki pedagogiczne, wychowawcze i higieniczne (znajdujemy w nich rady w zakresie doboru zabawek, informacje na temat znaczenia wychowawczego zabawek dla dzieci w określonym wieku), prasę pedagogiczną, kobiecą, rodzinną, społeczno-literacką, dziecięcą (tutaj, szczególnie w okresie przedświątecznym, zamieszczano porady z dziedzinie doboru zabawek, recenzje nowości rynku zabawkarskiego, reklamy składów z zabawkami, grafiki, powiastki, historyjki, wzory zabawek do samodzielnego wykonania), cenniki fabryk i składów zabawek (ukazywały repertuar zabawek produkowanych lub sprzedawanych przez daną firmę w określonym okresie i ich ceny), kalendarze (porady z zakresie doboru zabawek i reklamy), literaturę wspomnieniową i pamiętnikarstwo (autorzy wspomnień opisywali swoje zabawki świąteczne, ich rodzaje oraz sposoby wykorzystania), literaturę piękną i literaturę dla dzieci (powieści, nowele, powiastki, bajeczki, czy obrazki i wierszyki - ich autorzy chętnie i często czynili okres Świąt tłem dla fabuły utworów literackich), fotografię i świąteczne kartki pocztowe (ukazują rodzaje zabawek, ich wygląd); por. D. Żołądź-Strzelczyk i in., Dzieje zabawek dziecięcych, s. 32-60.

19 Źródłem bogatym w grafiki ukazujące zabawki są czasopisma dla dzieci. W niniejszym opracowaniu pominięto ten typ źródła, ponieważ zostanie on wykorzystany w przygotowywanym tekście dotyczącym zabawek dziecięcych w tekstach literackich i czasopismach adresowanych do dzieci.

${ }^{20}$ Stownik języka polskiego przez M.S.B. Linde, t. VI, U-Z, Warszawa 1814, s. 592.

${ }^{21}$ Stownik języka polskiego, obejmujący oprócz zbioru właściwie polskich, znaczna liczbę wyrazów z obcych języków [...] do podręcznego użytku, cz. 2, P-Ż, Wilno 1861, s. 2063; Z hasłem tym kore- 
W słowniku tym można również znaleźć określenie „zabaweczka” - z kwalifikatorem „pieszcz. (...) zabawka” ${ }^{22}$. W Stowniku języka polskiego podtug Lindego i innych nowszych źródeł Erazma Rykaczewskiego z 1866 roku termin zabawka ma dwa znaczenia. Pierwsze: „zdrob. mała zabawa, mała rozrywka”, drugie „to, czem się dzieci bawią. Kupiłem mu drewnianego konika na zabawkę"23. W 1869 roku jeden z przewodników higienicznych podawał: „przedmioty, które dzieciom do zabawy służą, nazywamy zabawkami" ${ }^{24}$. Z kolei Słownik języka polskiego z 1927 roku pod redakcją Jana Karłowicza, Adama Kryńskiego i Władysława Niedźwiedzkiego zabawką określał „przedmiot do zabawiania dzieci, cacko, zabaweczka, np. konik, lalka"25. Cel zaś zabawek stanowiło „dostarczenie dzieciom przyjemnych wrażeń, przyczyniających się bądź to pośrednio, bądź bezpośrednio do pomyślnego rozwoju władz fizycznych i umysłowych" ${ }^{26}$. W niniejszych rozważaniach, na podstawie analizy znaczeń terminu zabawka z XIX i początku XX wieku, przyjęto więc, że zabawką będzie przedmiot celowo wyprodukowany do zabawy ${ }^{27}$.

\section{Grafiki prasowe}

Na wiek XIX przypada niewątpliwie rozwój czasopiśmiennictwa. Co istotne $\mathrm{z}$ punktu widzenia poruszanego w niniejszym tekście zagadnienia, już od lat 20. tegoż wieku następuje rozwój ilustrowanych czasopism, a od lat 50. można datować niebywały rozkwit polskiej ilustracji prasowej, który swoje apogeum osiągnął w latach 1860-1880 na kartach „Tygodnika Ilustrowanego" i „Kłosów”28.

sponduje następne w kolejności: „Zabawkowy, (...) służący do zabawienia, od zabawek dziecinnych", tamże, s. 2063.

22 Tamże.

${ }^{23}$ E. Rykaczewski, Stownik języka polskiego podtug Lindego i innych nowszych źródet, t. II, Berlin - Poznań 1866, s. 1056.

${ }^{24}$ Przewodnik w zdrowym pieleggnowaniu dzieci od przyjścia na świat aż do dojrzenia, skreślony przez przyjaciela dzieci (lekarza), Lwów 1869, s. 84.

${ }^{25}$ Stownik języka polskiego, red. J. Karłowicz, A. Kryński, W. Niedźwiedzki, Warszawa 1927, z. 44, s. 17.

${ }^{26}$ R. Rogożewski, Jakie zabawki kupować dzieciom, „Dziecko” 1913, nr 9, s. 533. Por. M. Nawrot-Borowska, K. Kabacińska-Łuczak, Co podarować dziecku na Gwiazdkę?

${ }^{27}$ Por. współczesną definicję zabawki autorstwa Jana Bujaka: „przedmiot materialny specjalnie wykonany do celów zabawowych, który zawiera w sobie treści kulturowe właściwej dla niego epoki lub epok minionych z zakresu kultury materialnej, duchowej lub społecznej i przekazuje je w sposób budzący określone postawy ludyczny, a za ich pośrednictwem kształtuje rozwój fizyczny, psychiczny lub emocjonalny", J. Bujak, Zabawki w Europie. Zarys dziejów - rozwój zainteresowań, Kraków 1988, s. 15.

${ }_{28}$ M.A. Quinkenstein (red.), Grafika prasowa w XIX wieku, Kórnik 2007, s. 6; por. B. Szyndler, Tygodnik ilustrowany „Kłosy” (1865-1890), Wrocław 1981. 
Sceny prezentowane na grafikach prasowych pozwalają zobaczyć przede wszystkim wygląd zabawki, jej sposób wykonania, zdobienia. Ukazują także różnorodne sposoby wykorzystania zabawek przez dzieci, bowiem zabawki w tego rodzaju ilustracjach, w przeciwieństwie do form malarskich czy fotografii, zwykle przedstawiane są w scenach zabaw dziecięcych. Widzimy więc nie tylko czym, ale i jak bawiły się dzieci ${ }^{29}$.

Na prezentowanych wybranych grafikach czasopism adresowanych do dorosłych można znaleźć świąteczne zabawki dziecięce w różnych kontekstach: jako obiekt marzeń i westchnień (ryc. 1 i 2), jako prezent odbierany po wieczerzy wigilijnej (ryc. 3) i wręczany przez Gwiazdora (ryc. 4), jako przedmiot zabawy (ryc. 5, 6 i 7) oraz wyczekaną i ukochaną rzecz (ryc. 8, 9).

Zabawki umieszczone na świątecznej wystawie sklepowej są zapewne nierealnym marzeniem stojącej przed sklepem dziewczynki. Rysunek Ksawerego Pillatiego koresponduje z informacjami z działu „Kronika Tygodniowa”. Redakcja zwraca uwagę:

Jesteśmy więc w przeddzień świąt (...). Już jakiś bogaty dziadek kupił laleczkę dla swej wnuczki za 3,000 franków, ucząc ją rozrzutności zawczasu, zamiast tej niezaprzeczonej prawdy, że za te pieniądze możnaby obdarować lalkami z tysiąc dziewczątek, które się podarunku od nikogo spodziewać nie mają prawa ${ }^{30}$.

Zapewne taką dziewczynkę uwiecznił K. Pillati. Biedna, bosa, z podpartą na ręce głową, tęsknym wzrokiem wpatruje się w pięknie ubrane, kosztowne lalki. Oprócz nich na wystawie, w towarzystwie figurki Gwiazdora niosącego

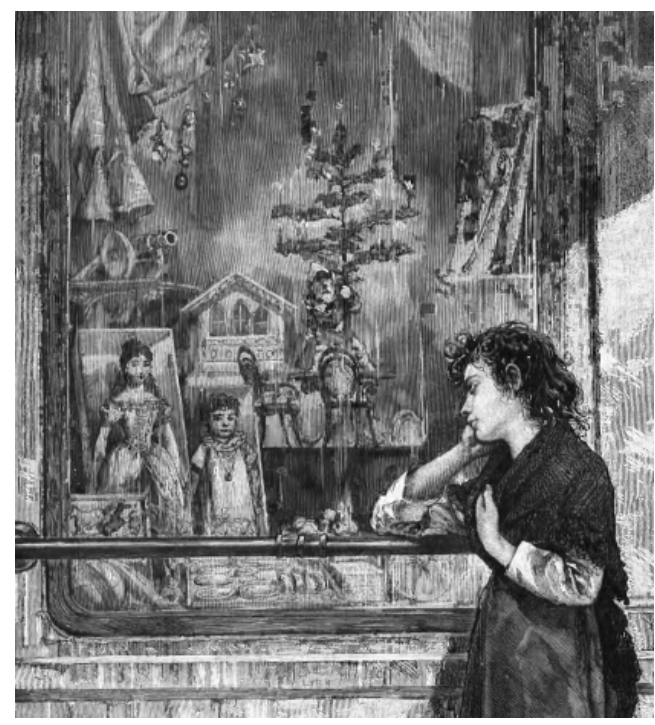
ustrojoną dziecinną choinkę, znajdują się między innymi: koniki, armata, domek, mebelki (krzesła i stolik) oraz serwis dla lalek - należące do kanonu najpopularniejszych zabawek badanego okresu.

Ryc. 1. "Nie dla mnie...", rysunek oryginalny Ksawerego Pillatiego (fragment grafiki)

(Źródło: „Tygodnik Ilustrowany” 1883, nr 51, s. 402)

\footnotetext{
${ }^{29}$ D. Żołądź-Strzelczyk i in., Dzieje zabawek dziecięcych, s. 34.
${ }^{30}$ Kronika Tygodniowa, „Tygodnik Ilustrowany” 1883, nr 51, s. 401.

${ }^{29}$ D. Żołądź-Strzelczyk i in., Dzieje zabawek dziecięcych, s. 34.
${ }^{30}$ Kronika Tygodniowa, „Tygodnik Ilustrowany” 1883, nr 51, s. 401.
} 
Marzenia o zabawkach leżących pod choinką zapewne zaprzątały umysły wielu dzieci. Być może maluchy także śniły o upragnionych przedmiotach. Tę właśnie tematykę podejmuje grafika, utrzymana w konwencji onirycznej, zamieszczona w czasopiśmie „Praca. Tygodnik polityczny i literacki, illustrowany" (ryc. 2). Nad dwójką śpiących dzieci czuwają aniołowie, z czułością pochylający się nad maleństwami. W dolnej części grafiki zostały umieszczone różne - cenne z punktu widzenia niniejszego opracowania - zabawki. Przy gałązkach choinkowych, symbolizujących czas bożonarodzeniowy, stoi piękny, misternie wykonany konik na biegunach, obok bębenek i trąbka, a poniżej strzelba. Przedmioty te mogą sugerować, że jednym ze śpiących dzieci jest chłopczyk, chcący bawić się w wojsko. Być może drugim dzieckiem jest dziewczynka, gdyż obok konika leży pięknie wystrojona lalka. Ponadto, można jeszcze dostrzec tablicę do rysowania, książeczkę z obrazkami oraz piłkę, co może sugerować, że adresatem tych zabawek były najmłodsze dzieci.

Pod grafiką znajduje się wierszyk Pauli Wężyk, w którym autorka w charakterystycznej dla ówczesnej poezji dziecięcej poetyce łączy owe marzenia dziecięce o przedmiocie materialnym z religijną wartością świąt Bożego Narodzenia.

Jak ptaszęta wpośród gniazdka Śpią dziateczki śpią

I prześlicznie śnią:

O laleczce i koniku,

O książeczce i biczyku,

O chojence ze świeczkami,

Z rumianemi jabłuszkami,

Śnią dziateczki śnią

I cichutko śpią.

A na niebie świeci gwiazdka,

Śpiewa Anioł Stróż:

Bóg się zrodził już!"31.

Ryc. 2. Sen dzieci

(Źródło: „Praca. Tygodnik polityczny i literacki, illustrowany" 1910, nr 52, s. 1643)

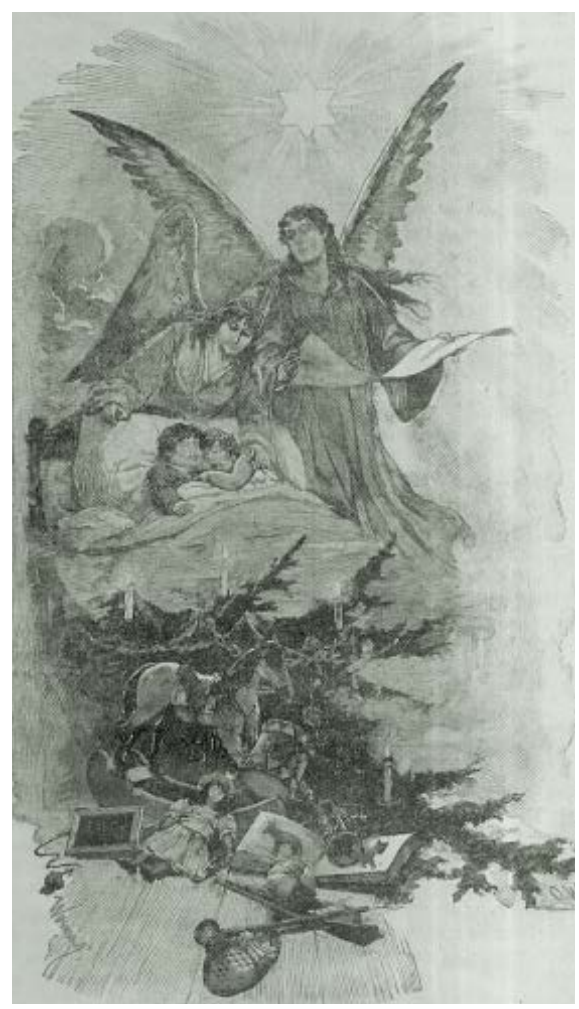

31 „Praca. Tygodnik polityczny i literacki, illustrowany” 1910, nr 52, s. 1643. 


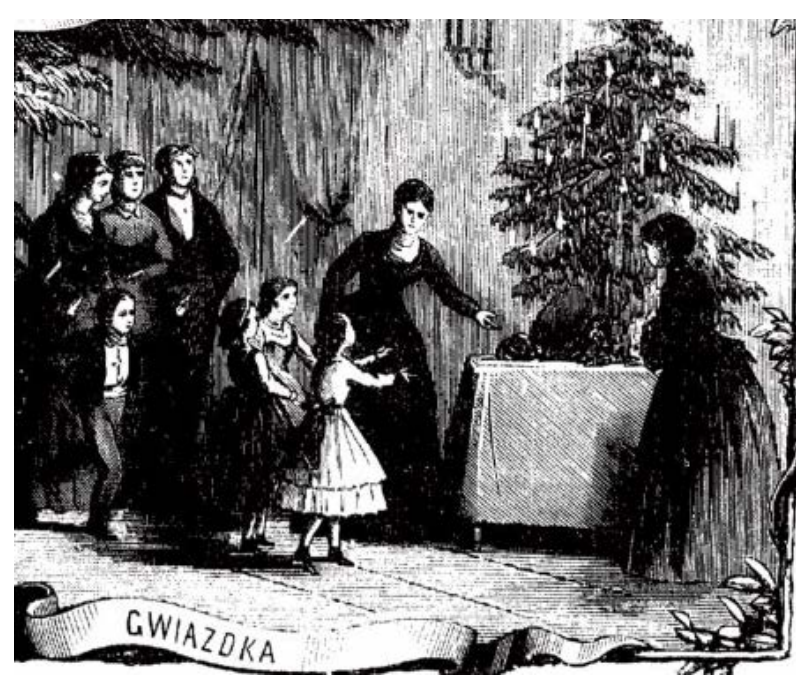

Ryc. 3. Gwiazdka (fragment grafiki)

(Źródło: „Kłosy” 1871, nr 338, s. 401)

Interesującym motywem zaprezentowanym na grafikach prasowych jest moment przekazywania prezentów dzieciom. Przykładem może być rycina 3 , stanowiąca fragment większej całości. Przedstawiono na niej „zebrane razem wszystkie obrzędy przywiązane do tych świąt, które pośród innych dorocznych, liczą się do najuroczystszych" 32. Upamiętniona została więc scena narodzin Pana Jezusa (w centrum) oraz pasterka odprawiana w drewnianym kościółku (u góry), szopka (po lewej), pokłon Trzech Króli (po prawej), a na dole grafiki wieczerza wigilijna (po lewej) oraz choinka (po prawej). Na tym właśnie fragmencie została uchwycona chwila, na którą w święta Bożego Narodzenia czekają wszystkie dzieci - wręczenie prezentów. Autor nie wyeksponował zabawek (pod choinką wyraźnie widać jednak różne, choć trudne do rozpoznania, przedmioty przeznaczone dla dzieci), ale ukazał dziecięce emocje towarzyszące oczekiwaniu na podarki wyciągnięte $\mathrm{w}$ górę ręce świadczą o radości i zniecierpliwieniu. Trzy dziewczynki stojące najbliżej choinki zostały przedstawione $\mathrm{w}$ momencie podchodzenia po prezenty wręczane przez stojące przy stole kobiety. Za nimi wbiega chłopczyk z podniesionymi do góry rękoma, jakby bał się, że spóźni się i upominków nie otrzyma.

W Wielkopolsce dzieci czekały na Gwiazdora, który w dużym worku przynosił wymarzone zabawki. Przykładem ilustracji tego zwyczaju może być grafika zamieszczona w czasopiśmie „Praca. Tygodnik polityczny i literacki, illustrowany" (ryc. 4) z 1910 roku. Gwiazdor wręcza prezenty dzieciom w różnym wieku. Jest to starszy mężczyzna z brodą, w długim płaszczu z kapturem i czapką na głowie. W jednej ręce trzyma pięknie przybraną, roziskrzoną świecami choinkę, w drugiej pęk rózg. Na plecach ma duży wór z prezentami, z którego wystają lalka i konik. Zwyczajem było, iż dziecko przed otrzymaniem upominku od Gwiazdora musiało powiedzieć modlitwę

${ }^{32}$ Boże Narodzenie, „Kłosy” 1871, nr 338, s. 400. 
lub wierszyk i wykazać, że było grzeczne - w przeciwnym razie zamiast prezentu otrzymywało rózgi. Dzieci, ustawione według wieku, czekają więc ze złożonymi do modlitwy rękoma na swoją kolej i wymarzony prezent. Uzupełnieniem tej ryciny jest wierszyk Pauli Wężyk, oddający doskonale specyfikę zachowania dzieci i nastrój chwili:

"Ojcze nasz, Zdrowaś i Wierzę",

Drżącym głosem i nieśmiało,

Ale serdecznie i szczerze,

Płynie z miłością nie małą.

Na czele idzie malutka,

Najmłodsza z gromadki dzieci:

„Gwiazdorku, grzeczna Helutka,

Daj tę choinkę co świeci!

"Gwiazdorku, rózgi nie trzeba!"

Jaś mały, Stasia i Józio,

Tak proszą wysłańca z nieba,

$\mathrm{Z}$ wystraszoną nieco buzią.

„Ulżyj twym barkom, Gwiazdorku!"

Tak Zosia i Zbyszek proszą,

Pokaż, co masz tam w tym worku,

Co będzie naszą rozkoszą?"

Lecz Gwiazdor stary, rzecz znana,

Wprzód długie prawi morały,

Więc słów tych dziatwo kochana

Oj, słuchaj z duszy twej całej!"33.

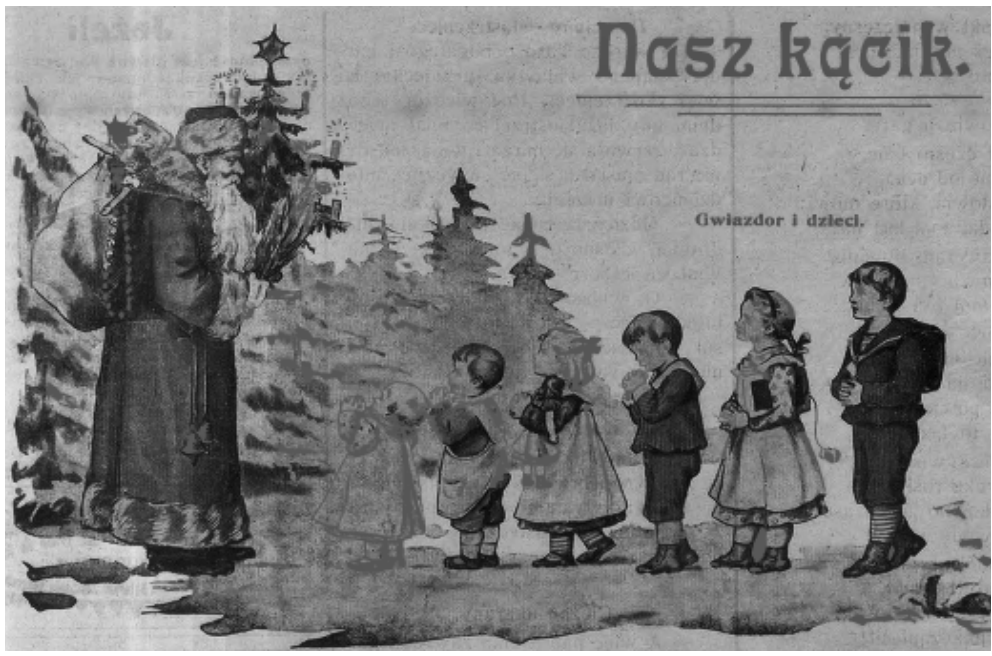

Ryc. 4. Gwiazdor i dzieci

(Źródło: „Praca. Tygodnik polityczny i literacki, illustrowany” 1910, nr 52, s. 1658)

${ }^{33}$ P. Wężyk, Gwiazdor i dzieci, „Praca. Tygodnik polityczny i literacki, illustrowany” 1910, nr 52, s. 1658. 


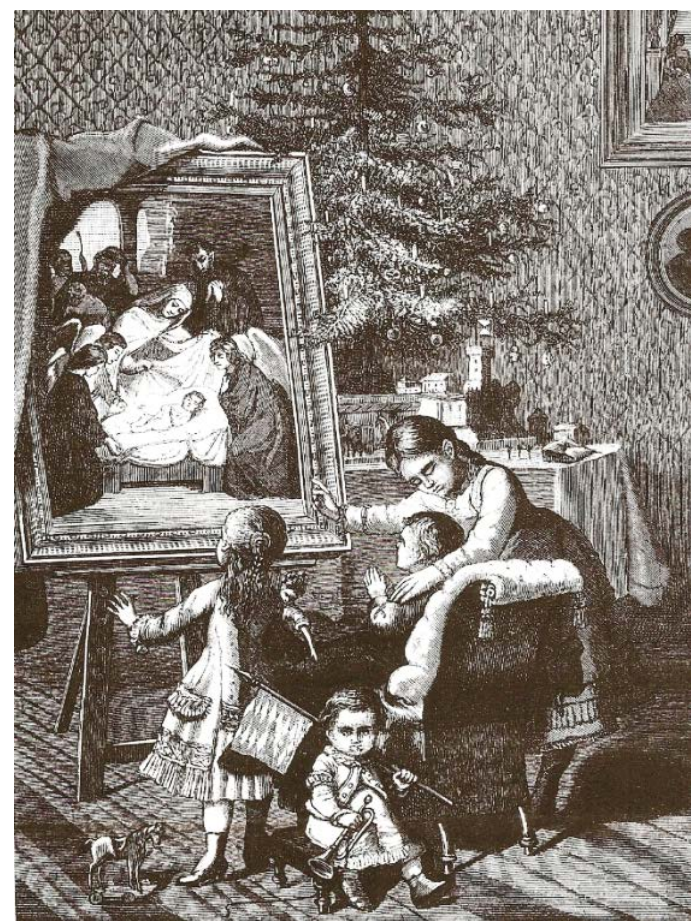

Ryc. 5. Gwiazdka

(Źródło: „Biesiada Literacka” 1886, nr 52, s. 402)

$\mathrm{Na}$ grafikach prasowych umieszczonych w czasopismach adresowanych do dorosłych nie ma zbyt wielu przedstawień bawiących się dzieci. Do wyjątków należy rycina $\mathrm{z}$ tytułowej strony „Biesiady Literackiej” z roku 1886 (ryc. 5), na której uchwycono scenę pokazania i zapewne wyjaśniania, o czym świadczy gest najstarszej dziewczynki, obrazu ukazującego moment narodzin Bożego Dziecka. Starsze dzieci - stojąca dziewczynka ściskająca $\mathrm{w}$ ręce lalkę i siedzące dziecko - z uwagą słuchają opowieści, najmłodszy maluch siedzi na małym krzesełku, $\mathrm{w}$ lewej $\mathrm{w}$ ręce trzyma chorągiew, w prawej trąbkę i biczyk - zapewne bawił się w musztrę lub inne zabawy żołnierskie. Tę tezę może potwierdzać stojący niedaleko dziecka konik na biegunach oraz znajdująca się pod choinką makieta zamku z wieżami, a także stajnie z konikami. Na grafice tej znalazły się zabawki „typowe” dla płci dziewczynka ma lalkę, chłopczyk konika, biczyk i trąbkę. Takie przedstawienie $\mathrm{w}$ pełni koresponduje $\mathrm{z}$ ówczesnymi poglądami na rolę zabawki, według których dziecko ma przygotować się do pełnienia odpowiednich ról w spo-

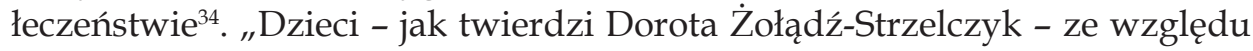
na przynależność do określonej płci bawiły się odpowiednimi zabawkami, naśladując obserwowane zachowania i zajęcia dorosłych"35.

Na rycinie 6 ukazano małą dziewczynkę pod choinką, trzymającą w ręku pajaca/arlekina. $\mathrm{W}$ objaśnieniu rycin redaktorzy $\mathrm{w}$ analizie poniżej ilustracji napisali: „Obrazek z tym podpisem nie potrzebuje objaśnienia długiego; kto

${ }^{34}$ Por. np. H. Wernic, Wychowanie dziecka: włącznie do lat 6-ciu, Warszawa 1902; tegoż, Praktyczny przewodnik wychowania, Warszawa 1891; E. J., Zabawki dziecinne, „Kłosy” 1885, nr 1068; [Józefa Jaxa-Bąkowska] Szczęsna, Zabawki dla dzieci, „Bluszcz” 1899, nr 50; Skarbiec dla rodzin w mieście i na wsi, wydawnictwo „Biesiady Literackiej”, t. 1, Warszawa 1888; J. Stella-Sawicki, Rady dla młodych mężatek, Warszawa 1910; A. Sobolewska, O zabawach i rozrywkach dziecięcych, "Wychowanie w Domu i Szkole” 1912.

${ }^{35}$ D. Żołądź-Strzelczyk, "A cacek téz dużo było", s. 7. 
na niego spojrzy, pojmie, iż to dziecko, ciesząc się z choinki gwiazdkowej, sięga po jabłko, mówiąc «Bozia dała»"36. W dalszej części akcentowali rolę wychowania religijnego w rozwoju dziecka i wpajania patriotyzmu. Z punktu widzenia niniejszej analizy, interesujące są zabawki otrzymane przez dziewczynkę w prezencie bożonarodzeniowym. Podnosząc rączkę po jabłko, dziewczynka przyciska do siebie pajacyka - postać z uwydatnionym nosem, w kombinezonie z kryzą pod szyją i szpiczastą czapką ${ }^{37}$. Pod choinką stoi owieczka. Figurki zwierząt były w badanym okresie jednym z ulubionych rodzajów zabawek młodszych i starszych dzieci. Ta zaprezentowana na grafice wydaje się być powleczona naturalną wełną ${ }^{38}$.

Specyfikę zabawek dziecięcych jako

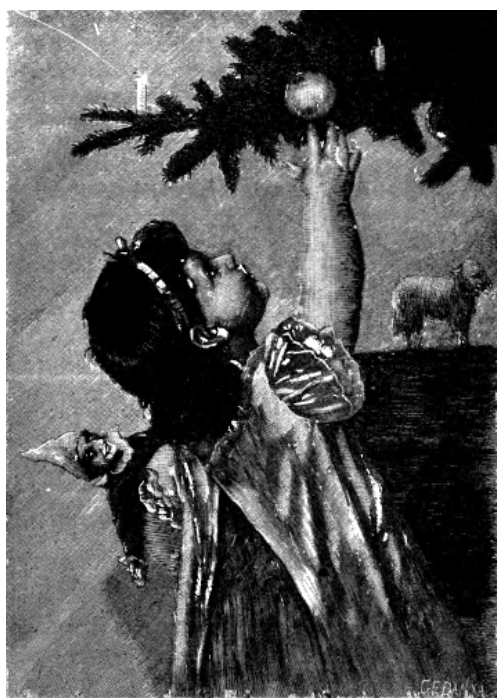

Ryc. 6. Dziewczynka pod choinką sięgająca po jabłko, „Bozia dała”

(Źródło: „Światło” 1892, nr 24, s. 372) przedmiotów zabawy z ostatnich dekad XIX wieku można zaobserwować na grafice niemieckiego artysty, opublikowanej w noworocznym numerze czasopisma „Kłosy” z 1880 roku (ryc. 7). Grafika nosi tytuł Choinka i jak opisała jej przekaz redakcja, autor „w tak oryginalny, naiwny, a pełny wdzięku sposób przeniósł w sfery niebieskie uciechy kolędowe ziemskiej dziatwy niewinnej" ${ }^{39}$. Aniołki przedstawione na grafice symbolizują dzieci, które radośnie przeżywają czas Bożego Narodzenia.

Widzimy, jak jedne uwijają się wkoło choinki, drugie przygotowują miłe niespodzianki wzajemne, te cieszą się podarkami otrzymanymi, tamte bawią się w strachy, jota $\mathrm{w}$ jotę jak ludzkie dzieci ${ }^{40}$.

Przyglądając się poszczególnym postaciom, w lewym górnym narożniku widzimy anioła szyjącego ubranka dla leżącej na stoliku małej laleczki, przed aniołem siedzącym pod ośnieżoną choinką stoi stolik pełen figurek żołnierzy, kominiarczyków i postaci gwiazdora z choinką. Anioł przebrany za doręczy-

36 Objaśnienia rycin, „Światło” 1892, nr 24, s. 384.

37 Pedagodzy i publicyści 2. połowy XIX wieku i początku XX stulecia nie zalecali kupowania dzieciom pajaców, arlekinów, ponieważ miały one psuć zmysł estetyczny oraz mogły wpłynąć szkodliwie na ich moralność, por. Pajace, [w:] Dzieje zabawek dziecięcych, s. 338-340.

${ }_{38}$ Tamże, s. 204-214.

${ }^{39}$ Choinka, „Kłosy”, 1880, nr 757, s. 6.

${ }^{40}$ Tamże. 

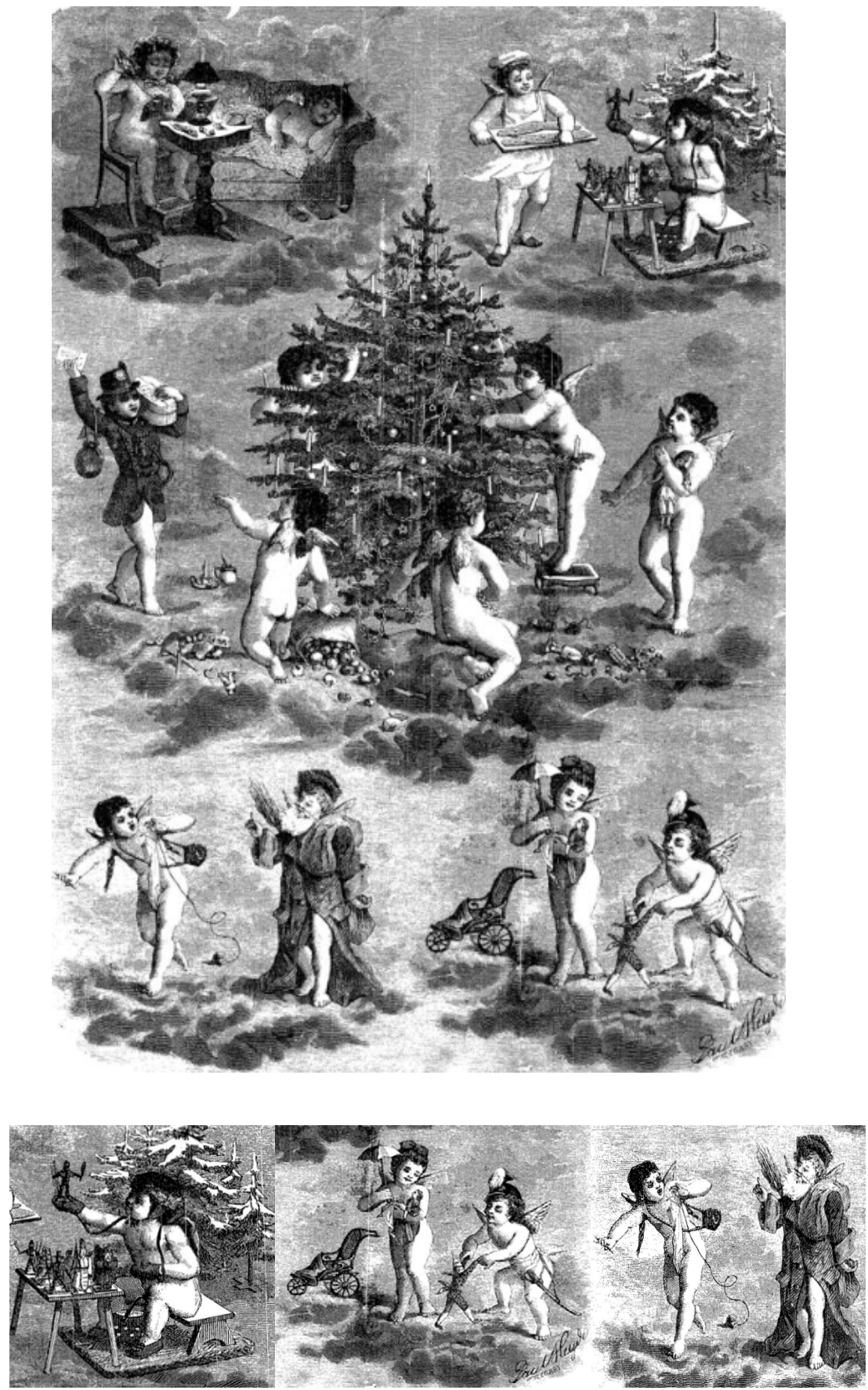

Ryc. 7. Choinka

(Źródło: „Kłosy” 1880, nr 757, s. 5) 
ciela poczty niesie pudełko cynowych figurek i piłkę $\mathrm{w}$ specjalnym worecz$\mathrm{ku}$, nagusek po prawej stronie choinki trzyma pod pachą pajacyka. Uciekający przed groźbami Gwiazdora aniołek ma na sznurku niewielką piłeczkę, zaś aniołek - dziewczynka zajął się zabawą lalką w długiej, strojnej sukience, lalczyną parasolką i spacerowym, trzykołowym wózkiem. Nie zabrakło też aniołka - żołnierza, który z szabelką u boku i wojskowej czapce uczy pajacyka musztry. U stóp aniołków skupionych najbliżej choinki, strojących ją, leżą figurki ludzików, pudełeczka, nożyczki, kubeczek z klejem, skrawki papierów i łupiny od orzechów - niezbędne do wykonywania zabawek choinkowych, świece oraz niewielkie jabłuszka, będące w XIX stuleciu popularną i smaczną ozdobą drzewka. Zabawy i zajęcia dziecinne przy choince przyrównane zostały w tekście komentującym grafikę do „nieba na ziemi”. Mimo że grafika jest autorstwa niemieckiego artysty, prezentowane na niej wokół choinki zabawki znajdowały się także w polskich domach, gdyż to właśnie z Niemiec chętnie i często je sprowadzano.

Wymarzone zabawki wzbudzały w dzieciach wiele emocji. Bywało również tak, że dzieci nienasycone zabawą nimi podczas zbyt krótkiego wigilijnego wieczoru, zmęczone towarzyszącym mu napięciem, zasypiały z wyczekaną zabawką (ryc. 8). Jedno ze śpiących dzieci nawet podczas snu nie wypuściło z rączki pajacyka.

Podobnie na rycinie 9 widzimy śpiące dzieci, które znużone wrażeniami wigilijnego wieczoru i zabawą wyczekiwanymi zabaw-

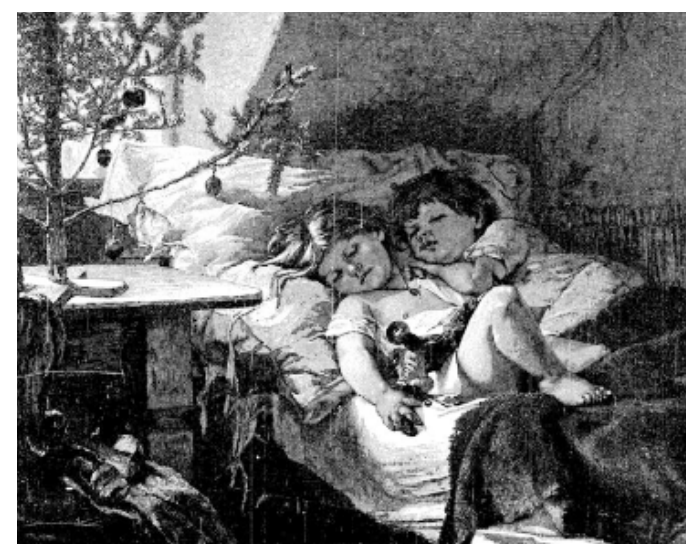

Ryc. 8. Poranek Bożego Narodzenia

(Źródło: „Kłosy” 1882, nr 913, s. 401) kami zasnęły w ich otoczeniu.

Dwoje dziatek niewinnych, zasypiających pod wrażeniem radości, jakie im gwiazda Chrystusowa przyniosła. Zasypane podarunkami, z duszyczką przepełnioną rajską błogością, ubawione aż do zanudzenia, toną we śnie cichym, rozkosznym, a wyraz ich uroczych, lubych twarzyczek domyślać się pozwala, iż widma rojące się w ich sennej wyobraźni muszą być niewątpliwie dalszym ciągiem słodkich upojeń, doświadczonych przez nie na jawie ${ }^{41}$.

${ }^{41}$ Na Gwiazdkę, „Kłosy” 1882, nr 912, s. 391. 


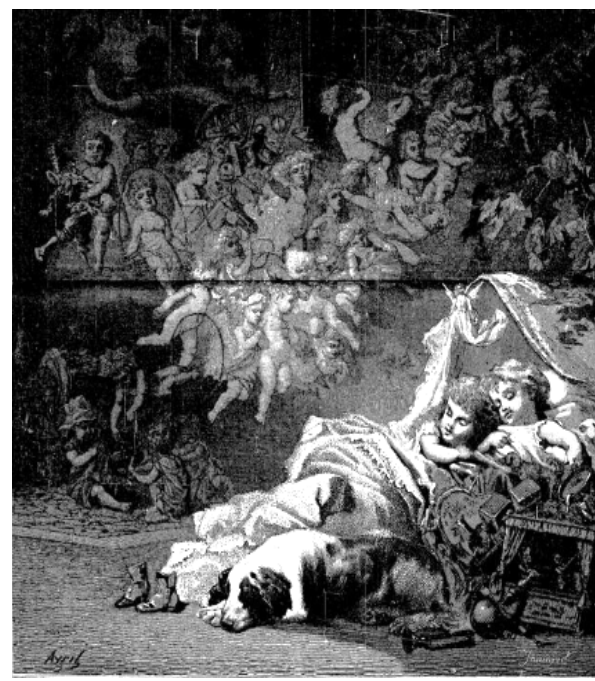

Ryc. 9. Senne marzenia dzieci w Wigilie Bożego Narodzenia, rysunek Avrila (Źródło: „Kłosy” 1882, nr 912, s. 392-393)
We śnie dziecinnym zabawom oddaje się rzesza aniołków, którym samo dzieciątko Jezus, piastowane przez Królową Anielską, sypie z rogu obfitości podarunki gwiazdkowe, by „nacieszyły się nimi na do woli, a potem je ziemskiej dziatwie na kolędę

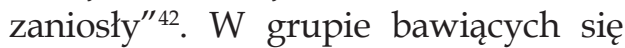
aniołków jeden jedzie na bujanym koniku, drugi gra na trąbce, trzeci trzyma w dłoniach dużą piłkę, czwarty pajaca, piąty obręcz do toczenia, inny skacze przez skakankę, zaś z rogu obfitości wysypują się najróżniejsze cacka - piłeczki, kręgle, bębenki. Przy śpiących dzieciach widzimy stos zabawek, wśród których znajduje się teatrzyk z figurkami - aktorami na scenie, figurka zwierzęcia (prawdopodobnie pieska), piłka, trąbka, kolejka.

\section{Kartki pocztowe}

Doskonałym źródłem do badania specyfiki zabawek dziecięcych, szczególnie początku XX wieku, są kartki pocztowe ${ }^{43}$. Stały się one powszechnym środkiem komunikacji międzyludzkiej u schyłku wieku XIX, a „złoty okres pocztówki" trwał do czasu I wojny światowej, kiedy drukowano je w największych nakładach, bogactwie motywów i na wysokim poziomie artystycznym ${ }^{44}$. Ówczesne kartki pocztowe okazały się wartościowymi obiektami kolekcjonerskimi, zaś ich szczególnym walorem jest wartość historyczno-dokumentacyjna. Stanowią one nośnik cennych informacji z przeszłości zarówno dla etnografów, socjologów, jak i historyków, czy historyków sztuki. Badać można zarówno awersy pocztówek, czyli ich warstwę ikonograficzną, jak i teksty zamieszczane przez piszących na ich rewersach.

Ilustrowane kartki pocztowe mają ogromną nośność informacyjną, dokumentacyjną i znaczeniową. Dawniej wydana pocztówka - podobnie jak dzieło sztuki, jeśli nie uległo zniszczeniu - żyje nadal (choć w innym kontekście), będąc autentycznym śla-

\footnotetext{
42 Tamże.

${ }^{43}$ O historii kart pocztowych zob.: J. Kotłowski, Złoty wiek pocztówki, Płock 1988.

44 J. Kotłowski, Pocztówki. Kolekcja biblioteki uniwersyteckiej w Toruniu, Toruń 1997, s. 8.
} 
dem przeszłości widzialnym dla każdego, kto pragnie je dostrzec. Dziś stare pocztówki (widokówki) stają się dla nas świadectwem lansowanych niegdyś wzorów - mody i gustów epoki; są dokumentami źródłowymi w badaniu historii, kultury ${ }^{45}$.

Okazuje się, że mogą one także służyć jako źródło do badania dziejów zabawek dziecięcych. W tym wypadku badaniu nie poddaje się tekstu pocztówki przesyłanego przez nadawcę, a obraz znajdujący się na jej awersie. Poszukując przekazów ikonograficznych poświęconych zabawkom, analizie warto poddać kartki okolicznościowe, czyli wysyłane z okazji różnorodnych świąt bądź uroczystości. Na potrzeby niniejszego tekstu analizie poddano okolicznościowe kartki przesyłane z okazji świąt Bożego Narodzenia.

Pocztówki okolicznościowe, na których przedstawione zostały zabawki dziecięce, rewers mają najczęściej w postaci czarno-białych lub kolorowanych fotografii (fotografia pocztówkowa). Często widnieje na nich scena rodzinna, przedstawiająca rodziców z dziećmi przy choince, pod którą ułożone zostały za-

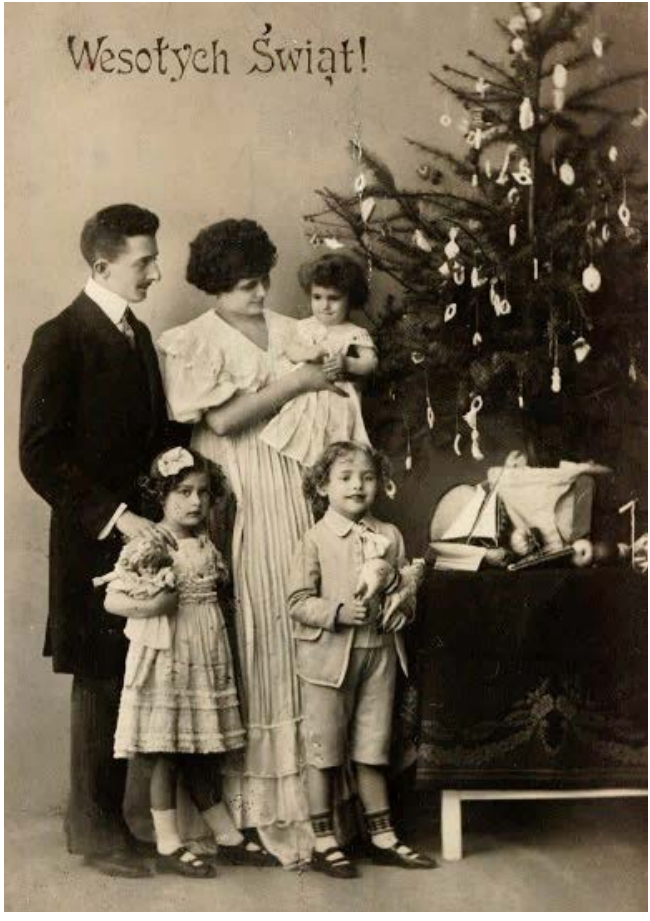

Ryc. 10. Rodzina przy choince, kartka pocztowa, początek XX wieku

(Źródło: Biblioteka Narodowa, Polona, domena publiczna) bawki. Bywa, że zabawki znajdują się także w rączkach dzieci. Analiza źródeł ikonograficznych pozwala stwierdzić, jakie zabawki były szczególnie popularne w okresie, zjakiego pochodzi dana pocztówka oraz które z bogatego asortymentu cacek dziecinnych szczególnie często znajdowały swoje miejsce pod choinką.

Na pocztówce datowanej na początek XX wieku (ryc. 10) widzimy pięcioosobową rodzinę przy choince, gdzie każde dziecko trzyma w rączkach zabawkę. Dziewczynka przytula niewielką, długowłosą lalkę ubraną $\mathrm{w}$ jasną sukienkę, chłopiec trzyma wełnianą owieczkę, prawdopodobnie wypchaną, z naturalnej owczej wełny. Trudno zidentyfikować zabawkę trzymaną przez najmłodsze dziecko; być może jest to jakaś grzechotka lub niewielka figurka. Pod choinką znajduje się piękna żaglówka, którą można było puszczać na wodzie.

45 Tamże, s. 9. 


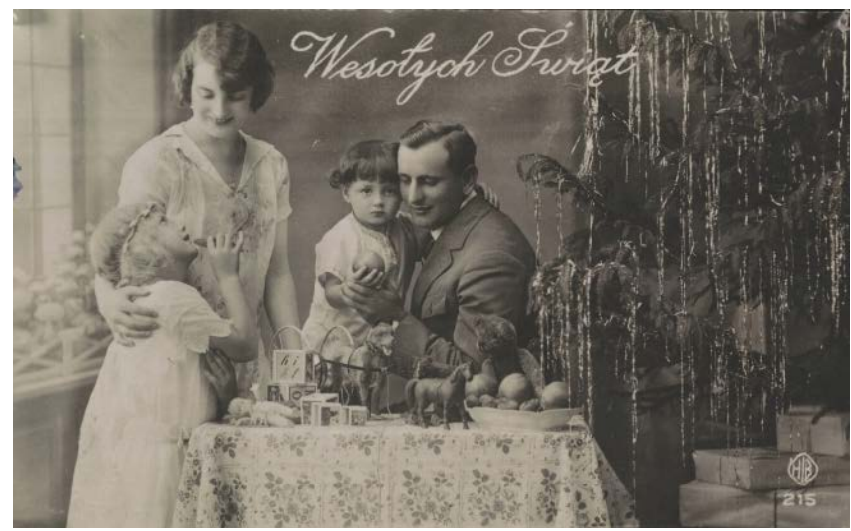

Ryc. 11. Rodzina przy choince i stoliku z zabawkami, kartka pocztowa, 1916 rok (Źródło: Biblioteka Narodowa, Polona, domena publiczna)

Na innej pocztówce (ryc. 11), datowanej na 1916 rok, świąteczne upominki i łakocie zostały wyeksponowane na specjalnym stoliku, przy którym obok choinki zgromadziła się rodzina. Wśród zabawek, które dzieci znalazły pod choinką, widzimy wózek dzwonkowy zaprzężony w dużego psa powleczonego sierścią (dzwonek znajdował się pomiędzy dużymi kołami zaprzęgu, kiedy dziecko wprawiało zabawkę w ruch, symulując ciągnięcie zaprzęgu przez psa, dzwonek wydawał dźwięk), klocki z literami i obrazkami (różnej wielkości klocki pozwalały ustawić z nich wieżę - od największego do najmniejszego), figurkę konika (prawdopodobnie odlaną z celuloidu), pluszowego misia, pluszowego kota na platformie z kółkami, laleczkę niemowlę, małą drewnianą figurkę owieczki na platformie. Dziewczynka przykłada jakiś przedmiot do ust - być może jest to gwizdek. Ułożenie zabawek zaprezentowane na pocztówce może sugerować, które $\mathrm{z}$ nich były przeznaczone dla dziewczynki, a które dla chłopca.

Częstym motywem prezentowanym na kartkach świątecznych była

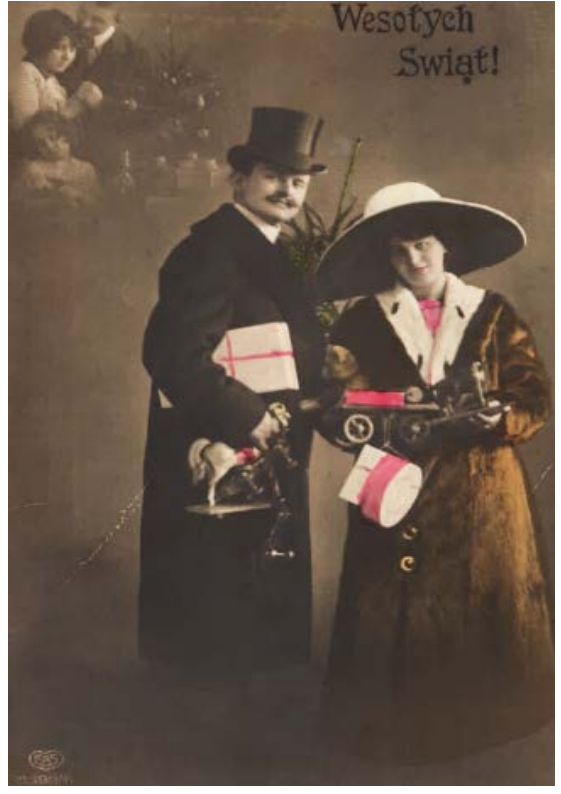

Ryc. 12. Z podarkami, pocztówka, po roku 1900

(Źródło: Biblioteka Narodowa, Polona, domena publiczna) 


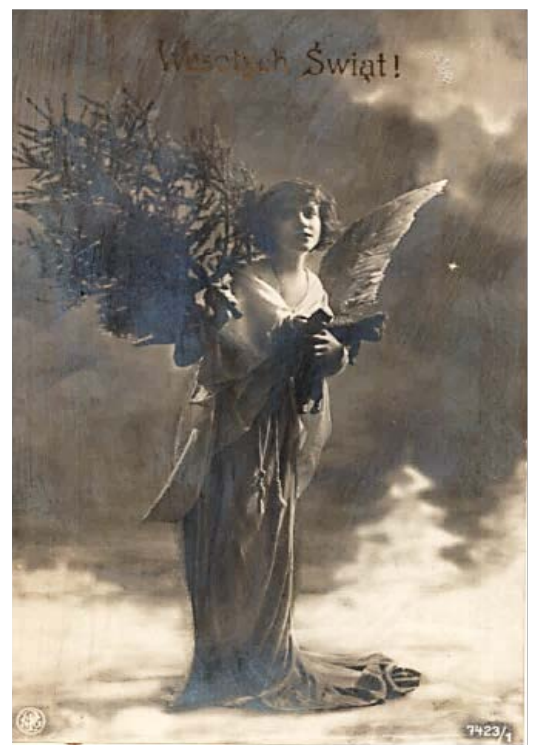

Ryc. 13. Kobieta $w$ przebraniu anioła niosaca choinke $i$ zabawki dla dzieci, pocztówka, początek XX wieku

(Źródło: Biblioteka Narodowa, Polona, domena publiczna)

para niosąca bożonarodzeniowe drzewko oraz szereg paczek i paczuszek, w których znajdowały się podarki dla najbliższych. Wśród tych prezentów często były także zabawki dla najmłodszych. Na rycinie 12, datowanej na początek XX wieku, wśród różnych pakunków mężczyzna trzyma dziecięce wrotki, białego konika na platformie, kobieta natomiast brązowego pluszowego misia, pojazd na kołach i drewniane zwierzątko na platformie. W lewym górnym rogu pocztówki można dostrzec świąteczną scenę rodzinną - trzymający się za ręce rodzice stoją obok przybranego drzewka, pod którym ułożono prezenty, w tym konika na platformie. Dzieczynka przygląda się nowej laleczce, przytulając ją z miłością.

W Małopolsce i na Podkarpaciu prezenty najmłodszym przynosił Aniołek, dlatego również jego postać umieszczano na kartkach pocztowych. Na jednej z nich (ryc. 13) kobieta w stroju anioła niesie na ramieniu choinkę, a w lewej ręce trzyma pluszowego misia oraz lalkę - żołnierza.

\section{Fotografia}

Wynaleziona u schyłku 1. połowy XIX wieku fotografia szybko stała się popularnym, choć stosunkowo jeszcze wówczas kosztownym sposobem zatrzymywania chwil na cienkim papierku, naklejonym na tekturowy kartonik. Łatwo zauważyć, iż ukazane powyżej kartki pocztowe przygotowywane były właśnie na podstawie fotografii. Zdjęcia takie wykonywano najczęściej w pracowni fotografa, w specjalnie wykreowanej scenografii i ustalonych pozach. Odpowiednio przygotowaną fotografię powielano, po uprzednim naniesieniu na niej napisu „Wesołych Świąt” i w ten oto sposób powstawała fotografia pocztówkowa.

„Od pierwszych lat istnienia fotografii to nowe medium postrzegano jako pomoc historyczną" ${ }^{46}$. Fotografie na potrzeby prywatne wykonywano

${ }^{46}$ Fotografie i portrety, [w:] P. Burke, Naoczność. Materiaty wizualne jako świadectwa historyczne, Kraków 2012, s. 39. 


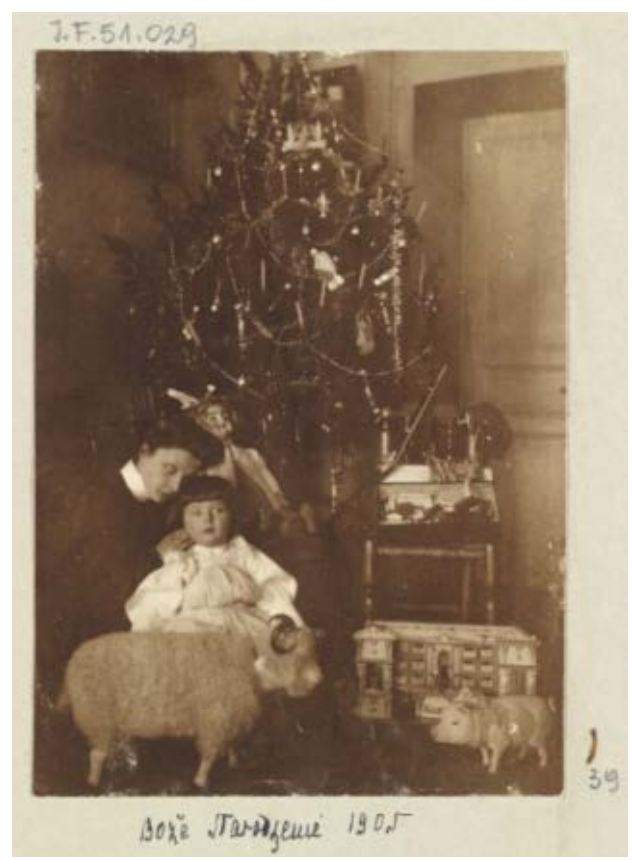

Ryc. 14. Eugenia Brzezińska z synem przy choince, Boże Narodzenie 1905 roku (Źródło: Biblioteka Narodowa, Polona, domena publiczna)

zarówno w fotograficznych atelier - wówczas dzieci najczęściej pozowały z zabawką - jak i w domach, kiedy uwieczniano między innymi świąteczne uroczystości. Wtedy to interesujące nas zabawki umieszczano najczęściej pod choinką.

Święta Bożego Narodzenia należały do chwil, które wśród zamożnych rodzin chętnie uwieczniano na fotografiach, utrwalając radosny nastrój i wspólnie spędzany czas. Na fotografiach z okresu Świąt zwykle widnieje wigilijny stół lub choinka, wokół niej skupiona rodzina, w otoczeniu podarków, także zabawek. Niezwykle bogaty zestaw wartościowych zabawek widzimy na fotografii, której bohaterką jest Eugenia Brzezińska z synem (ryc. 14). Dzieci, których w rodzinie było troje (dwóch chłopców i dziewczynka), znalazły pod choinką naturalnych rozmiarów wypchanego i powleczonego owczą wełną barana, dużą figurkę świnki, makietę sklepu z figurką sprzedawcy oraz dużą biskwitową lalkę. Na krześle w pudełku znajduje się zestaw do budowania torów kolejowych, na oparciu zawieszono strzelbę dziecinną oraz wojskową czapkę i trąbkę w kształcie rogu. Większość tych zabawek była pochodzenia zagranicznego, zapewne sprowadzona na specjalne zamówienie.

Jak wspomniano, na fotografiach zabawki najczęściej znajdowały się pod choinką. Przykładem różnorodności świątecznych zabawek dziecięcych może 


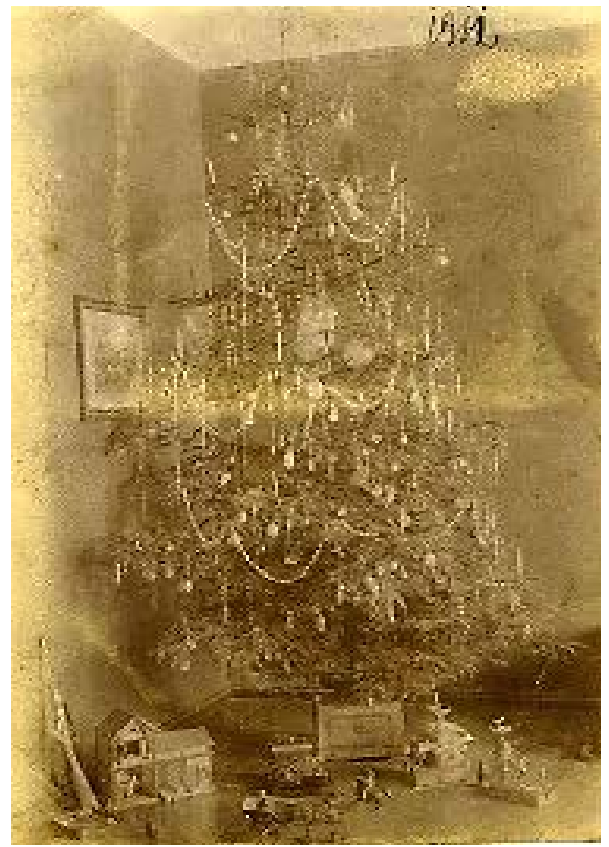

Ryc. 15. Choinka, 1911 rok

(Źródło: Muzeum Narodowe Rolnictwa i Przemysłu Rolno-Spożywczego w Szreniawie)

być poniższa fotografia (ryc. 15), datowana na rok 1911. W narożniku pokoju stoi udekorowane okazałe drzewko, a pod nim znajdują się poukładane - zapewne w celu wykonania zdjęcia - zabawki. Można dostrzec typowo chłopięce przedmioty zabawy: opartą o ścianę strzelbę, wóz z konikami, jeźdźców na koniach, stajnię z figurkami zwierząt, zabawki z figurkami wprawianymi w ruch obrotowy oraz jakieś machiny. Większość zabawek wyeksponowanych pod choinką została wykonana $\mathrm{z}$ drewna.

\section{Podsumowanie}

Jakie więc zabawki otrzymywały dzieci na Boże Narodzenie? Jaki był stosunek maluchów do prezentów świątecznych? Odpowiedzi na te pytania można znaleźć analizując źródła ikonograficzne.

Zabawka - z jednej strony - odzwierciedla tradycjonalizm, konserwatyzm dziecięcego świata, czego przejawem jest ukształtowany w początkowych okresach dziejów podstawowy kanon zabawek dziecięcych, z drugiej zaś jest odbiciem wielorakich przemian technologicznych, kulturowych, obyczajowych, estetycznych ${ }^{47}$.

\footnotetext{
${ }^{47}$ D. Żołądź-Strzelczyk i in., Dzieje zabawek dziecięcych, s. 8.
} 
Prezentowane ryciny obrazują różnorodność dziecięcych zabawek. Są one odbiciem tradycyjnego podziału na zabawki dziewczęce (lalka, wózek) i chłopięce (konik, biczyk, bębenek, strzelba), przygotowujące do pełnienia odpowiednich ról społecznych. Można znaleźć zarówno proste, wykonane z drewna, przedmioty zabawy, jak też eleganckie, drogie, sprowadzane z zagranicy. Najczęściej przedstawiano zabawki - figurki (konika, pajaca, owieczki itp.), czyli przedmioty, które dziecko mogło chwycić w ręce lub przytulić. Autorzy analizowanych ilustracji starali się uwiecznić także emocje towarzyszące dzieciom podczas otrzymywania zabawek świątecznych. Najczęściej trzymały one podarunek, tuliły go, a nawet z nim spały. Ważne podkreślenia są twarze dzieci, ich postawy ciała ukazane w momencie oczekiwania na prezenty. Duże oczy, szeroki uśmiech, błogość, ale także lekkie przerażanie przed spotkaniem z Gwiazdorem - to uczucia znane również współczesnym dzieciom wypatrującym pierwszej gwiazdki i... prezentów pod choinką.

Na zakończenie należy podkreślić, że na wszystkich przedstawieniach omówionych w niniejszej analizie znajdują się pewne atrybuty świąt Bożego Narodzenia - choinka, Gwiazdor, aniołek, prezenty. Dzieci, uczestnicząc w obchodach świątecznych, nabywały odpowiednich kompetencji kulturowych. Poprzez trwanie $\mathrm{w}$ tradycjach i zwyczajach bożonarodzeniowych uczyły się nie tylko znaczenia religijnego roku liturgicznego, ale także przyjmowały i przejmowały klimat rodzinnych świąt. Dzięki owej tradycji, święta Bożego Narodzenia mają także dla współczesnych niezapomnianą atmosferę.

\section{BIBLIOGRAFIA}

\section{Źródła}

\section{Pisane}

Arcta M., Stownik ilustrowany języka polskiego, Warszawa 1916.

Bartynowski M., Obchód świąt Bożego Narodzenia w Polsce. (Kilka szczegótów z dziedziny prawa kanonicznego i archeologii), Kraków 1887.

Biart L., Pogadanki braci z siostrami, spisane ku zabawie młodych czytelników, przekł J. Chęciński, Warszawa 1875.

Boże Narodzenie, „Kłosy” 1871, nr 338.

Choinka, „Kłosy” 1880, nr 757, s. 6.

E. J., Zabawki dziecinne, „Kłosy” 1885, nr 1068.

Gloger Z., Encyklopedia staropolska ilustrowana, Warszawa 1901.

Gloger Z., Encyklopedia staropolska, t. I, Warszawa 1900.

Gloger Z., Encyklopedia staropolska, t. II, Warszawa 1901.

Gloger Z., Encyklopedia staropolska, t. III, Warszawa 1902.

[Józefa Jaxa-Bąkowska] Szczęsna, Zabawki dla dzieci, „Bluszcz” 1899, nr 50.

Kantor J., Zwyczaje świąt Bożego Narodzenia i Wielkiej Nocy w okolicy Jarosławia, Kraków 1913. 
Kronika Tygodniowa, „Tygodnik Ilustrowany” 1883, nr 51.

Lalka. Podarunek młodym panieneczkom z obrazkami. Rozmowy, powiastki, bajeczki dla dzieci, Lwów, ok. 1850.

„Myśl Niepodległa” 1910, nr 156.

Na Gwiazdke, „Kłosy” 1882, nr 912.

Objaśnienia rycin, „Światło” 1892, nr 24.

Przerwa-Tetmajer W., Gody i godne święta czyli Okres świąt Bożego Narodzenia w Krakowskiem, Kraków 1898.

Przewodnik o zdrowym pielęgnowaniu dzieci od przyjścia na świat aż do dojrzenia, skreślony przez przyjaciela dzieci (lekarza), Lwów 1869.

Rogożewski R., Jakie zabawki kupować dzieciom, „Dziecko” 1913, nr 9.

Rykaczewski E., Stownik języka polskiego podtug Lindego i innych nowszych źródet, t. II, Berlin - Poznań 1866.

Skarbiec dla rodzin w mieście i na wsi, wydawnictwo „Biesiady Literackiej”, t. 1, Warszawa 1888.

Stownik jezyka polskiego przez M.S.B. Linde, t. VI, U-Z, Warszawa 1814.

Stownik języka polskiego, obejmujący oprócz zbioru właściwie polskich, znaczną liczbę wyrazów z obcych języków [...] do podręcznego użytku, cz. 2, P-Ż, Wilno 1861.

Stownik języka polskiego, red. J. Karłowicz, A. Kryński, W. Niedźwiedzki, Warszawa 1927, z. 44.

Sobolewska A., O zabawach i rozrywkach dziecięcych, "Wychowanie w Domu i Szkole” 1912.

Stella-Sawicki J., Rady dla młodych mężatek, Warszawa 1910.

Styczeń. Kolęda, [w:] Powieści moralne dla dzieci. Przez autorkę „Pamiątki po dobrej matce”, Warszawa 1820.

Wernic H., Praktyczny przewodnik wychowania, Warszawa 1891.

Wernic H., Wychowanie dziecka: włącznie do lat 6-ciu, Warszawa 1902.

Wężyk P., Gwiazdor i dzieci, „Praca. Tygodnik polityczny i literacki, illustrowany” 1910, nr 52.

\section{Ikonograficzne}

„Bozia dała”, „Światło” 1892, nr 24.

Choinka, Muzeum Narodowe Rolnictwa i Przemysłu Rolno-Spożywczego w Szreniawie, 1911.

Eugenia Brzezińska z synem przy choince, Boże Narodzenie 1905 r., Biblioteka Narodowa, Polona, domena publiczna.

Gwiazdka (fragment grafiki), „Kłosy” 1871, nr 338.

Gwiazdka, „Biesiada Literacka” 1886, nr 52.

Gwiazdor i dzieci, „Praca. Tygodnik polityczny i literacki, illustrowany” 1910, nr 52.

Kobieta w przebraniu anioła niosąca choinkę i zabawki dla dzieci, pocztówka, początek XX wie$\mathrm{ku}$, Biblioteka Narodowa, Polona, domena publiczna.

„Nie dla mnie...", rysunek oryginalny Ksawerego Pillatiego (fragment grafiki), „Tygodnik Ilustrowany" 1883, nr 51.

Poranek Bożego Narodzenia, „Kłosy” 1882, nr 913.

Rodzina przy choince, kartka pocztowa, początek XX wieku, Biblioteka Narodowa, Polona, domena publiczna.

Sen dzieci, „Praca. Tygodnik polityczny i literacki, illustrowany” 1910, nr 52.

Senne marzenia dzieci w Wigilię Bożego Narodzenia, rysunek Avrila, „Kłosy” 1882, nr 912.

Z podarkami, pocztówka, po 1900 r., Biblioteka Narodowa, Polona, domena publiczna. 


\section{Opracowania}

Bibliografia Historii Wielkopolski za lata 1939-2000 osoby A-Ż, Biblioteka PTPN, http:/ /www. biblioteka.ptpn.poznan.pl/sites/default/files/bibliografiaosoby.pdf (22.02.2018).

Bujak J., Zabawki w Europie. Zarys dziejów - rozwój zainteresowań, Kraków 1988.

Burke P., Naoczność. Materiały wizualne jako świadectwa historyczne, Kraków 2012.

Kabacińska K., Zabawy i zabawki dziecięce w osiemnastowiecznej Polsce, Poznań 2007.

Kabacińska K., Zabawy i zabawki dziecięce w świetle polskiej nowelistyki pozytywistycznej, Zabawy i Zabawki, 2008, 1-4.

Kabacińska K., Od grzechotki do... - stów kilka o zabawkach dziecięcych, Studia Edukacyjne, 2010, 11.

Kabacińska-Łuczak K., Ratajczak K., Dziecko chłopskie w czasie sacrum - konteksty edukacyjne (średniowiecze-epoka nowożytna), Studia Edukacyjne, 2013, 28.

Kabacińska-Łuczak K., Ratajczak K., Dynamika przemian od społeczeństwa tradycyjnego do ery nowoczesności, [w:] Rekonstrukcje tożsamości w kulturze natychmiastowości, red. D. Hejwosz-Gromkowska, Poznań 2014.

Kotłowski J., Złoty wiek pocztówki, Płock 1988.

Kotłowski J., Pocztówki. Kolekcja biblioteki uniwersyteckiej w Toruniu, Torun 1997.

Nadrowski H., Sacrum czasoprzestrzeni - reinterpretacja - kontrowersje - świat wartości, Torun 2012.

Nawrot-Borowska M., Zabawy i zabawki dziecięce w drugiej połowie XIX i na początku XX wieku - wybrane problemy z wykorzystaniem grafik z epoki, Biuletyn Historii Wychowania, $2013,30$.

Nawrot-Borowska M., Obrazki z dziejów lalki, [w:] Z badań nad tradycją polskiej pedagogiki, t. 2: Księga jubileuszowa dedykowana Profesor Danucie Koźmian, red. E. Magiera, J. Król, Szczecin 2016.

Nawrot-Borowska M., Kabacińska-Łuczak K., Co podarować dziecku na Gwiazdkę? Porady pedagogiczne i ferty reklamowe dla kupujacych zabawki z II połowy XIX i początku XX wieku (w druku).

Quinkenstein M.A. (red.), Grafika prasowa w XIX wieku, Kórnik 2007.

Szyndler B., Tygodnik ilustrowany "Kłosy” (1865-1890), Wrocław 1981.

Wojciechowska B., Od Godów do świętej Łucji. Obrzędy doroczne w Polsce późnego średniowie$c z a$, Kielce 2000.

Zabawka - przedmiot ludyczny i obiekt kolekcjonerski, red. K. Kabacińska-Łuczak, D. Żołądź-Strzelczyk, Poznań 2016.

Żołądź-Strzelczyk D., "A cacek też dużo było”. Zabawki dziecięce na ziemiach polskich w średniowieczu i epoce nowożytnej, Kwartalnik Historyczny, 2013, 1.

Żołądź-Strzelczyk D., Rola zabawek w przygotowaniu do petnienia ról społecznych kobiecych i męskich w epoce nowożytnej, [w:] Kobieta i mężczyzna jedna przestrzeń - dwa światy, red.

B. Popiołek, A. Chłosta-Sikorska, M. Gadocha, Warszawa 2015.

Żołądź-Strzelczyk D., Kabacińska K. (red.), Dawne zabawy dziecięce, Kielce - Warszawa 2008.

Żołądź-Strzelczyk D., Kabacińska K. (red.), Dawne i wspótczesne zabawki dziecięce, Poznań 2010.

Żołądź-Strzelczyk D., Gomułka I., Kabacińska-Łuczak K., Nawrot-Borowska M., Dzieje zabawek dziecięcych na ziemiach polskich do początku XX wieku, Wrocław 2016. 